\title{
The main risk factors for the number of serious or critical cases of covid-19: how is the health of Brazilians?
}

Haniel Soares Fernandes ${ }^{1}$

${ }^{1}$ Faculdade Estácio de Sá, Departamento de nutrição, Fortaleza, Ceará, Brasil

${ }^{1}$ Faculdade São Gabriel da Palha, Nutrição, metabolismo e fisiologia no esporte, Minas Gerais, Brasil

${ }^{1}$ Faculdade de Economia, Administração, Atuariais e Contábeis, Universidade Federal do Ceará, Fortaleza, Ceará, Brasil

${ }^{1}$ https://orcid.org/0000-0003-0971-482X

1Haniel_fernandes@hotmail.com

\begin{abstract}
Chronic noncommunicable diseases (CNCDs) have been a major public health concern worldwide, especially diabetes, cardiovascular disease, chronic obstructive pulmonary disease, hypertension, in addition to obesity, which is even more worrying when the subject involves the covid-19 pandemic, because such incidences correlate with the need for intensive care units, including the possibility of death of the patient. Therefore, for countries with the highest numbers of critical cases, it is important to assess the incidence of these diseases to guide the public that most needs guidance on public policies for social isolation.
\end{abstract}

Keywords: Covid-19, Epidemiology, Chronic diseases, Serious or critical cases, Brazil, Coronavirus.

\section{Introduction}

In mid-November 2019 in China, a new respiratory infection started, SarsCov-2 (severe acute respiratory syndrome coronavirus 2), also known as Covid-19 (coronavirus disease 19), which until January this year arrived to almost 80,000 confirmed cases and due to the high transmissibility power from human to human, where an infected person can infect six other individuals, a pandemic was declared on March 11,2020 by the World Health Organization (WHO) ${ }^{1,2}$. With the coming of the pandemic, the concern of patients who are part of the risk group for covid-19 grows and it is up to the understanding about which incidences and which are these diseases that make coronavirus infection more serious or critical. 


\section{The new coronavirus pandemic and its main risk factors}

Recent studies have managed to investigate the main risk groups that, from contamination by coronavirus, are more likely to become serious or critical cases, requiring the ICU (intensive care unit) or dying from covid-19. These cases mainly involve people diagnosed with chronic noncommunicable diseases (NCDs) ${ }^{3}$, in particular, hypertension, cardiovascular disease, diabetes and lung diseases, including age as another important risk factor, for individuals over $60^{4-7}$. Regarding the age of the inhabitants, between 60 and 69 years, Brazil has just over 16 million inhabitants, against almost 40 million among North Americans, just over 7.5 million for the French and almost 5 million among Spaniards ${ }^{8}$. Another recent study correlated the age and BMI (body mass index) of patients admitted to the ICU by covid-19 and observed that, in addition to age, high BMI may be directly related to the need for intensive care beds on the part of these cases ${ }^{9}$.

Worldometer, a reference site that provides real-time statistical data for various topics, contains graphs containing all countries that officially declare the number of people infected with covid-19. In addition, statistical data on coronavirus mortality are also demonstrated. The mortality rate by age is around 3.6\% between 60 and 69 years old, $8 \%$ between 70 and 79 years old and $14 \%$ for those over 80 years old, whereas for the comorbidities mentioned above, the mortality rates are $6 \%$ for hypertensive patients, $6.3 \%$ for pulmonary diseases, $7.3 \%$ for diabetics and $10.5 \%$ for cardiac patients ${ }^{10}$. There is also the possibility of correlating data with a dynamic table that, in addition to the total number of contaminated, brings the total number of patients in critical condition. Where, when selecting this column in ascending order of cases, we have the United States leading the ranking with 16,481 records, followed by Brazil, France, Spain, with 8,318, 2,564, 5,252 , respectively ${ }^{10}$. This raises several questions, including whether the Brazilian population actually has more NCDs and contains a greater number of elderly people than the French and Spanish population.

Therefore, a recent study evaluated mortality from ischemic heart disease between 2005 and 2015 and concluded the number of deaths in 366,801 in the United States, 111,849 in Brazil, 33,769 in Spain and 32,727 in France ${ }^{11}$. Another study classified the same percentage of prevalence of hypertension among men, from $30 \%$ to 31.9\%, for North Americans, French, Spanish and Brazilians, whereas for the female population, the rates were between 32 and 33.9\% among Brazilian and North American 
versus less than $28 \%$ for French and Spanish ${ }^{12}$. According to the OECD (organization for economic co-operation and development), the global prevalence for type 1 and 2 diabetes among adults aged 20 to 79 years is $10.8 \%, 10.4 \%, 7.7 \%$ and $5.1 \%$ among Americans, Brazilians, Spanish and Italians respectively ${ }^{13}$ and the prevalence of chronic obstructive pulmonary disease (COPD) is between 8.1 and 12\% among Brazilians, 12.1 to $16 \%$ among Americans and 6 to $12 \%$ for French and Spanish ${ }^{14,15}$.

In Brazil, 74\% of deaths were caused by CNCDs, with emphasis on ischemic heart disease $(28 \%)^{3}$. The percentage of deaths from ischemic heart disease among 4059 year olds is around $10.6 \%$ among men and $8.4 \%$ among women ${ }^{16}$, among individuals over 60 this percentage rises to $11.2 \%$ among men and to $10.2 \%$ among women ${ }^{16}$. The percentage of deaths from diabetes and COPD (chronic obstructive pulmonary disease) among elderly men is $5 \%$ and $5.3 \%$ respectively ${ }^{16}$. Among elderly women, the percentage of deaths from diabetes and hypertension is $6.7 \%$ and $5.4 \%$ respectively ${ }^{16}$. A recent survey concluded that in Brazil, $24.7 \%$ of the population has a diagnosis of hypertension, of these $60.9 \%$ are over $65,{ }^{17}$ and $7.1 \%$ of men and $8.1 \%$ of women for diabetes, of these $24 \%$ are over $65^{18}$.

\section{Conclusion}

Observations of the main comorbidities, diabetes, hypertension, cardiovascular disease, lung disease, in addition to obesity and age over 60 years, can be feasible to understand the number of serious or critical cases in intensive care units in countries like Brazil, United States, France and Spain, and perhaps making the public most in need of public policies of social isolation viable.

\section{References}

1. Livingston E, Bucher K, Rekito A. Coronavirus Disease 2019 and Influenza 2019-2020. Jama. 2020;323(12):1122. doi:10.1001/jama.2020.2633

2. Liu Y, Gayle AA, Wilder-Smith A, Rocklöv J. The reproductive number of COVID-19 is higher compared to SARS coronavirus. J Travel Med. 2020;27(2):1-6. doi:10.1093/jtm/taaa021

3. Jiang B, Lan S, Wilt K, et al. World Health Statistics 2018: Monitoring Health for the SDGs, Sustainable Development Goals. Vol 5.; 2018. doi:10.1016/j.ijmachtools.2009.09.004 
4. Lei Fang, George Karakiulakis MR. Are patients with hypertension and diabetes mellitus at increased risk for COVID-19 infection? 2020;(March). doi:https://doi.org/10.1016/ S2213-2600(20)30116-8

5. Lippi G, Henry BM. Chronic obstructive pulmonary disease is associated with severe coronavirus disease 2019 (COVID-19). 2020;(January). doi:https://doi.org/10.1016/ j.rmed.2020.105941

6. Bo Xu MUGK. Open access epidemiological data from the COVID-19 outbreak. 2020;(February):19-20. doi:https://doi.org/10.1016/ S1473-3099(20)30119-5

7. Weiss P, Murdoch DR. Clinical course and mortality risk of severe COVID-19 COVID-19 : towards controlling of a pandemic. Lancet. 2020;395(10229):10141015. doi:10.1016/S0140-6736(20)30633-4

8. Pyramid P. Pirâmides Populacionais do Mundo desde 1950 até 2100. https://www.populationpyramid.net/pt/brasil/2019/. Published 2019. Accessed May 1, 2020.

9. Kass DA, Duggal P, Cingolani O. Obesity could shift severe COVID-19 disease to younger ages. Lancet. 2020;6736(20):19-20. doi:10.1016/S01406736(20)31024-2

10. WorldoMeter. COVID-19 CORONAVIRUS PANDEMIC. https://www.worldometers.info/coronavirus/\#countries. Published 2020. Accessed May 1, 2020.

11. Nowbar AN, Gitto M, Howard JP, Francis DP, Al-Lamee R. Mortality from ischemic heart disease: Analysis of data from the world health organization and coronary artery disease risk factors from NCD risk factor collaboration. Circ Cardiovasc Qual Outcomes. 2019;12(6):1-11. doi:10.1161/CIRCOUTCOMES.118.005375

12. Mills KT, Bundy JD, Kelly TN, et al. Global disparities of hypertension prevalence and control. Circulation. 2016;134(6):441-450. doi:10.1161/CIRCULATIONAHA.115.018912

13. Federation ID. Diabetes prevalence. 2018;387(2016):106-107. doi:10.1787/health_glance_eur-2018-18-en 
14. Blanco I, Diego I, Bueno P, Casas-Maldonado F, Miravitlles M. Geographic distribution of COPD prevalence in the world displayed by Geographic Information System maps. Eur Respir J. 2019;54(1). doi:10.1183/13993003.00610-2019

15. Lamprecht B, Soriano JB, Studnicka M, et al. Determinants of underdiagnosis of COPD in national and international surveys. Chest. 2015;148(4):971-985. doi:10.1378/chest.14-2535

16. Brasil. Saúde Brasil 2017: Uma Análise Da Situação de Saúde e Os Desafios Para o Alcance Dos Objetivos de Desenvolvimento Sustentável.; 2018. http://bvsms.saude.gov.br/bvs/publicacoes/saude_brasil_2017_analise_situacao_s aude_desafios_objetivos_desenvolvimento_sustetantavel.pdf.

17. Brasil M da saude. Estimativas Sobre Frequência e Distribuição Sociodemográfica de Fatores de Risco e Proteção Para Doenças Crônicas Nas Capitais Dos 26 Estados Brasileiros e No Distrito Federal Em 2019.; 2019. https://www.saude.gov.br/images/pdf/2020/April/27/vigitel-brasil-2019vigilancia-fatores-risco.pdf.

18. Sartorelli D saes, Franco LJ. Tendências do diabetes mellitus no Brasil. Cad Saúde Pública, Rio Janeiro, . 2018:29-36. 